\title{
USLE Estimation for Potential Erosion at Wae Heru Watershed and Wae Tonahitu Watershed, Ambon Island, Indonesia
}

\author{
Halvina Grasela Saiya, Suprapto Dibyosaputro and Sigit Herumurti Budi Santosa
}

Received: 25042015 / Accepted: 09082015 / Published online: 30122016

C 2016 Faculty of Geography UGM and The Indonesian Geographers Association

\begin{abstract}
Calculate the potential erosion at Wae Heru and Wae Tonahitu Watershed aims to map and assess the potential erosion, in order to be a scientific consideration for exploration and development. The method is a field survey to determine the forms of land use and other forms of conservation efforts; secondary data collection, i.e. soil data, rainfall data, slopes data and data interpretation from Geo Eye satellite imagery in 2012. Further data processing used USLE formula with ArcGIS program. The results showed that the potential erosion of Wae Heru Watershed and Wae Tonahitu Watershed are in very light potential class. This is because the conditions in the upstream are still forested largely. However, at the downstream potential for erosion is vary, i.e. light class, moderate class, heavy class and very heavy class. This is because the conditions in the downstream undergo conversion into settlement, moor, garden, open land and sand mining.
\end{abstract}

Keywords: Erosion, Potential Erosion, USLE, Watershed

Abstrak Menghitung potensi erosi di Wae Heru dan Wae Tonahitu Daerah Aliran Sungai bertujuan untuk memetakan dan menilai potensi erosi, agar menjadi pertimbangan ilmiah untuk eksplorasi dan pengembangan. Metode ini adalah survei lapangan untuk menentukan bentuk penggunaan lahan dan bentuk lain dari upaya konservasi; pengumpulan data sekunder, data tanah yaitu, data curah hujan, data yang lereng dan interpretasi data dari citra satelit Geo Eye pada tahun 2012. pengolahan data lebih lanjut digunakan rumus USLE program ArcGIS. Hasil penelitian menunjukkan bahwa erosi potensi Wae Heru DAS dan Wae Tonahitu Daerah Aliran Sungai di kelas potensial sangat ringan. Hal ini karena kondisi di hulu masih berhutan sebagian besar. Namun, pada potensi hilir erosi adalah bervariasi, yaitu kelas ringan, kelas menengah, kelas berat dan kelas yang sangat berat. Hal ini karena kondisi di hilir mengalami konversi menjadi pemukiman, tegalan, kebun, lahan terbuka dan penambangan pasir.

Kata kunci : Erosi, Potensi erosi, USLE, Daerah Aliran Sungai

\section{Introduction}

Hydrological system is a combination of a complex interaction of several factors namely geomorphology, hydrogeology, biological processes in it and land use practice. Condition of hydrological system can affect redistribution of subsurface water storage in soils and groundwater contribution. An example of one very important hydrological system is watershed. Management and protection of the watersheds is one of the major concern of the $21^{\text {st }}$ century (Walia and Mipun, 2010).

Halvina Grasela Saiya, Suprapto Dibyosaputro dan Sigit Herumurti Budi Santosa

Faculty, Gadjah Mada University, Yogyakarta, Indonesia

Email : halvina.grasela@mail.ugm.ac.id

Geomorphological conditions on Ambon Island, especially in the Ambon City, consists of hilly areas mostly, with steep slopes of $\pm 186,90 \mathrm{~km}^{2}$ and plain areas with a slope of about $10 \%$ has an area of $\pm 55 \mathrm{~km}^{2}$ of its total land area. Subdistrict of Baguala Ambon Bay which is part of the Ambon city has many watersheds in both large and small, and there are two largest watershed, that is Wae Heru Watershed with a river length of $3.50 \mathrm{Km}$ and Wae Tonahitu Watershed with a river length of $6.00 \mathrm{Km}$ (Asikin, 1999; Ambon City in Numbers, 2012 and Subdistrict of Baguala Ambon Bay in Numbers, 2012). Both of the Watershed ends in Inner Ambon Bay.

Based on that, the potential erosion will be very high and erosion will be happen certainly 
when the rainy season. Moreover, the pattern of improper land use, often occurs in Ambon (Loppies, 1992; Latupono, 2005). Then, the erosion that occurs all along the watershed also influence the conditions in Inner Ambon Bay, so that the calculation of the potential erosion needs to be done.

In hydrology, watershed conditions that exist in the study area, generally have a kind of dendritic stream-flow patterns with an elongated shape that growth to be parallel patterns (Sahuleka, 1993). Soil drainage is generally good, except in the form of units of plains alluvial coastal freshwater and brackish (Siahaya, 1998). According to Berhitu and Matakupan (2010), rivers that are in the research sites, in general, has undergone a process of silting due to deposition of sand. This is caused by the use of non-agricultural land in the buffer zone and the treatment for a conservation area less attention to the factors that may cause damage to the land. So, therefore water catchment areas are not maintained then the fluctuations of river flow in the dry season and the rainy season is quite large. Frequent droughts in the dry season, while frequent flooding during the rainy season. Tokarczyk (2013) state that drought means a lack of water which normally would be available in a region. During the hydrological drought period, the effects of water scarcity have an impact on almost all economic activities and, although in extreme cases, the supply of fresh water might be limited. Then, managing of water resources needs to be done.

Based on these things then, that will be studied in this research is what are the estimation of potential erosion at Wae Heru Watershed and Wae Tonahitu Watershed? The aims to map and assess the potential erosion that exist in the two watersheds, in order to be a scientific consideration in the future exploration and development in order to face of human population growth which is increasing rapidly. The increase in this growth can be seen in the city of Ambon statistical data in 2015 showing that, since 2000 to 2014, always an increasing number of population and never once occurred a decline in population. With an average population growth rate of $4.7 \%$ per year. On the statistical data recorded in 2000 there were 209303 inhabitants and in 2014 there were 395423 inhabitants.

\section{The Methods}

This research was conducted from May-July 2013, located in the Wae Heru Watershed and the Wae Tonahitu Watershed (Figure 1).

To estimate the potential for erosion, by collecting rainfall data, slope, soil characteristics, land use from the interpretation of satellite imagery and field observations. Then the data is calculated by USLE (Universal Soil Loss Equation) approach (Wischmeier and Smith, 1978), i.e.:

$$
\mathrm{A}=\mathrm{R} \cdot \mathrm{K} \cdot \mathrm{LS} \cdot \mathrm{C} \cdot \mathrm{P}
$$

With, $\mathrm{A}=$ soil loss (tons/hectares/year); $\mathrm{R}=$ rainfall

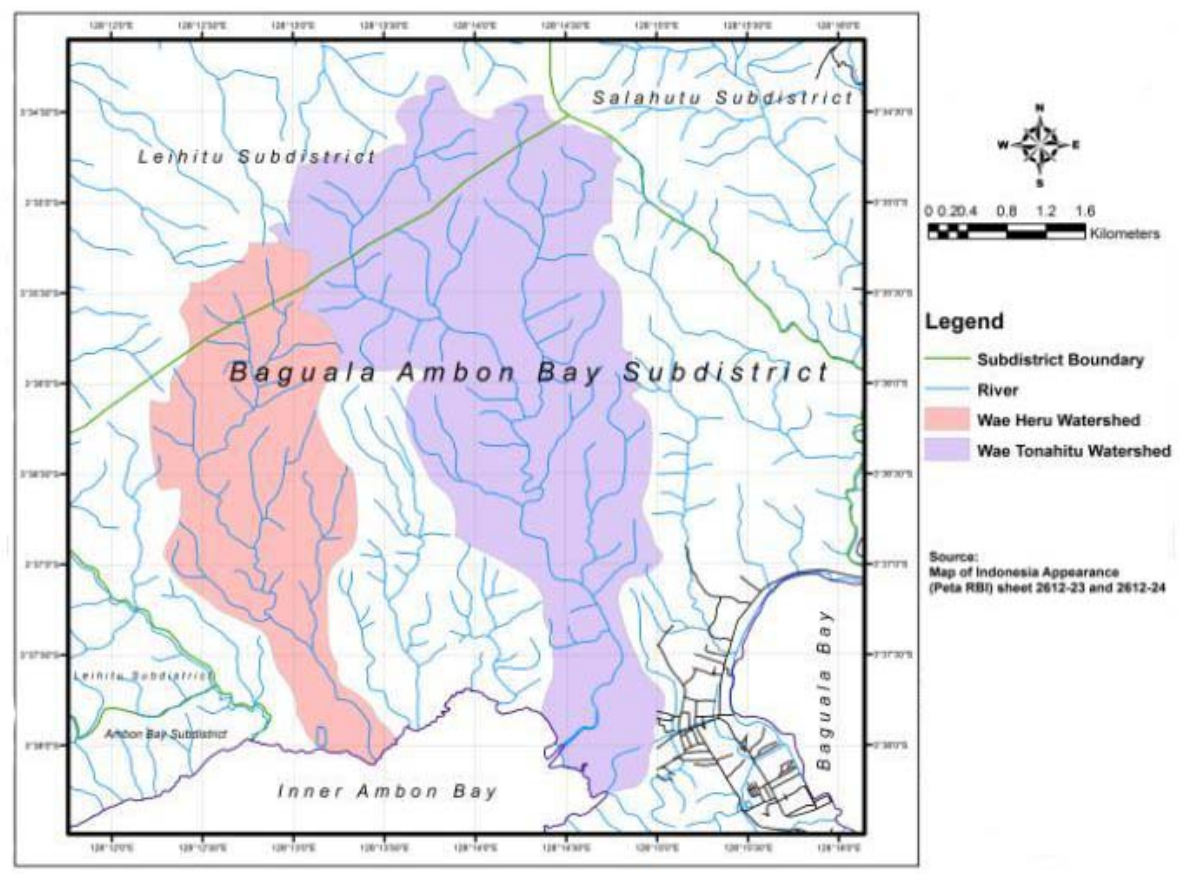

Figure 1. Map of Two Watersheds as Research Area 
erosivity index (tons/year); $\mathrm{K}=$ soil erodibility index; LS = index of slope and slope length; $\mathrm{C}=$ index of vegetation cover (land use); dan $\mathrm{P}=$ soil conservation index.

Rainfall erosivity is obtained by using the Lenvain formula (Asdak, 2002), i.e.:

$$
\mathrm{R}=2.21 \times \mathrm{P}^{1,36}
$$

With, $\mathrm{R}=$ rainfall erosivity index (tons/year); $\mathrm{P}=$ monthly rainfall $(\mathrm{cm})$. Furthermore, to obtain annual rainfall erosivity is obtained by adding up all the monthly rainfall erosivity in one year.

Soil erodibility value obtained by secondary data from Department of Agriculture for soil types in Indonesia. The types of soil in the study area based on research from Siahaya (1998) is alluvial, kambisol, gleisol and podzolic, so that the value of the land erodibilitas can be seen in Table 1 .

While the LS index value obtained based on the classification of the Forestry Department which can be seen in Table 2 .

Then, the value of $\mathrm{C}$ and $\mathrm{P}$ are determined based on the classification of Arsyad (2006), which is shown in Tables 3 and 4.

Class of potential erosion is determined by reference to the blend of the lost ground with soil solum levels, as shown in Table 5:

Table 1. Determining the value of soil erodibility for the type of soil in the study area based on secondary data

\begin{tabular}{|c|c|c|}
\hline Soil Types & Value of $\mathrm{K}$ & Data Source \\
\hline Alluvial & 0.47 & Departement of Agriculture, 2004 \\
\hline Kambisol & 0.25 & Hammer in Departement of Agriculture, 2004 \\
\hline Gleisol & 0.315 & Hammer in Departement of Agriculture, 2004 \\
\hline Podzolic & 0.16 & $\begin{array}{l}\text { Hammer, Undang and Suwardjo in Departement of Agriculture, } \\
2004\end{array}$ \\
\hline
\end{tabular}

Source: Departement of Agriculture (2004)

Table 2. Ratings for LS Factors Using Class of Slopes

\begin{tabular}{ll}
\hline Class of Slopes $(\%)$ & Value of LS \\
\hline $0-8$ & 0.25 \\
$8-15$ & 1.4 \\
$15-25$ & 3.1 \\
$25-40$ & 6.8 \\
$>40$ & 9.5 \\
\hline
\end{tabular}

Source: Departement of Forestry (1994)

Table 3. Value of $\mathrm{C}$ for different types of crops and land cover and crop management

\begin{tabular}{ll}
\hline Sorts of Use & Value of $^{*}$ \\
\hline Ground open / no crop & 1.000 \\
paddy field & 0.010 \\
Moor is not specified & 0.700 \\
Cassava & 0.800 \\
Corn & 0.700 \\
Soy & 0.399 \\
Potato & 0.400 \\
Peanuts & 0.200 \\
Paddy & 0.561 \\
Cane & 0.200 \\
Banana & 0.600 \\
Fragrant roots (lemongrass) & 0.400 \\
Grass Bede (the first year) & 0.287
\end{tabular}


Grass Bede (the second year)

0.002

Coffee with poor ground cover

0.200

Taro

0.850

mixed farms

- High Density

$\begin{array}{ll}\text { - Moderate Density } & 0.200 \\ \text { - Low Density } & 0.500\end{array}$

Shifting

0.400

natural forest

0.001

- a lot of litter

$$
\text { - a little of litter }
$$

Production forest

- Clearfelling

Shrub / grassland

Cassava + soybean

- Selective logging

0.200

0.300

Cassava + peanut

0.181

Rice + sorghum

0.195

0.345

Rice + soya

0.417

Peanuts + pigeonpea

0.495

Peanuts + cowpea

0.571

Peanuts + straw mulch 4 tons / hectare $\quad 0.049$

Rice + straw mulch 4 ton / hectare $\quad 0.049$

Peanuts + corn mulch 4 tons / hectare $\quad 0.128$

Peanuts + Crotalaria mulch 3 tons / hectare $\quad 0.136$

Peanuts + cowpea mulch $\quad 0.259$

Peanuts + straw mulch 2 tons / hectare $\quad 0.377$

Rice + Croalana mulch 3 tons / hectare $\quad 0.387$

Cropping patterns overlap shift ${ }^{* *}+$ straw mulch $\quad 0.079$

Sequential cropping patterns ${ }^{* *}+$ mulch of crop residues $\quad 0.357$

Imperata pure fertile

0.001

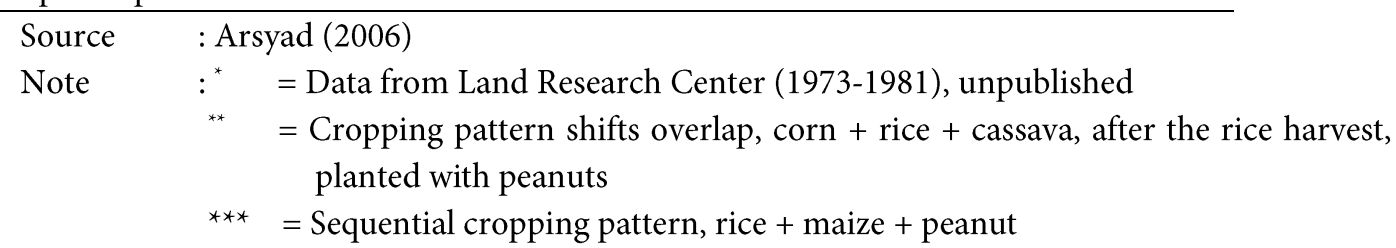

Table 4. The value of $\mathrm{P}$ for a variety of special soil conservation acts

\begin{tabular}{ll}
\hline Special Measures for Soil Conservation & Value of P \\
\hline Bench terracing & \\
- Good Construction & 0.040 \\
- Moderate Construction & 0.150 \\
- Unfavorable Construction & 0.350 \\
- Traditional terrace & 0.400 \\
Strip bahia grass plants & 0.400 \\
Soil management and cultivation according to the contour lines & \\
- The slope of 0-8\% & 0.500 \\
- The slope of 9-20\% & 0.750 \\
- The slope of >20\% & 0.900 \\
Without conservation acts on land & 1.000 \\
\hline
\end{tabular}

Source: Arsyad (2006) 
Table 5. Classes for Erosion Hazard Level

\begin{tabular}{|c|c|c|c|c|c|}
\hline \multirow{2}{*}{ Erosion } & \multicolumn{5}{|c|}{ Class of Erosion } \\
\hline & I & II & III & IV & $\mathrm{V}$ \\
\hline Solum levels & \multicolumn{5}{|c|}{ Erosion (tons/hectares/year) } \\
\hline$(\mathrm{cm})$ & $<15$ & $15-60$ & $60-180$ & $180-480$ & $>480$ \\
\hline Deep & VL & $\mathrm{L}$ & M & $\mathrm{H}$ & VH \\
\hline$>90$ & 0 & I & II & III & IV \\
\hline Moderate & $\mathrm{L}$ & M & $\mathrm{H}$ & $\mathrm{VH}$ & $\mathrm{VH}$ \\
\hline $60-90$ & I & II & III & IV & IV \\
\hline Shallow & M & $\mathrm{H}$ & $\mathrm{VH}$ & $\mathrm{VH}$ & $\mathrm{VH}$ \\
\hline $30-60$ & II & III & IV & IV & IV \\
\hline Very Shallow & $\mathrm{H}$ & $\mathrm{VH}$ & $\mathrm{VH}$ & $\mathrm{VH}$ & $\mathrm{VH}$ \\
\hline$<30$ & III & IV & IV & IV & IV \\
\hline
\end{tabular}

Source: Directorate General of Reforestation and Land Rehabilitation (1998);

Note: $\mathrm{VL}=$ very light, $\mathrm{L}=$ light, $\mathrm{M}=$ moderate, $\mathrm{H}=$ heavy, $\mathrm{VH}=$ very heavy

Furthermore, the data calculation results were processed with ArcGIS 9.3 to produce a map of erosion class. The data used are secondary data, that is: slope data sourced from data of Development Planning Agency at Ambon City in 2008, soil type data sourced from Research conduct by Siahaya on 1998, land use data extracted from GeoEye imagery in 2012 as well as data of rainfall during the year 2012 were obtained from the data of Meteorology Climatology and Geophysics Council, Class of 1a, Pattimura Stations, Ambon. Coupled with field observations to ensure the results of image interpretation of GeoEye imagery.

\section{Results and Discussion}

The calculation can be seen in Table 6. Thus, the value of the rainfall erosivity index (R) of 5312.68 tons/year.

\section{a. Determination of the value of $K$}

Soil erodibility $(\mathrm{K})$ is determined by Table 1 . Here are explanations of each type of soil.

The alluvial soil is a kind of undeveloped land with layered deposition. Average soil depth is 79 $\mathrm{cm}$ with an effective soil depth is very deep (130 $\mathrm{cm})$. Soil color is dark brown with sandy loam texture, fine granular, friable, fast permeability with $\mathrm{pH}$ 5.5-6.0. This soil type is grown from the parent material of young alluvium and spread on land form the old beach and floodplains (Sahuleka, 1993; Siahaya, 1998 and Samalehu, 2013).

Table 6. The Calculation of Rainfall Erosivity Index in 2012

\begin{tabular}{lcrrr}
\hline \multirow{2}{*}{ Month } & Rainfall $(\mathrm{mm})$ & $\begin{array}{c}\text { Rainfall } \\
(\mathrm{cm})\end{array}$ & $\mathrm{P}^{1.36}$ & $\begin{array}{c}\text { 2.21 } \times \mathrm{P}^{1.36} \\
\text { (tons/year) }\end{array}$ \\
\hline January & 99.7 & 9.97 & 22.81526 & 50.42172379 \\
February & 119.1 & 11.91 & 29.05628 & 64.21437639 \\
March & 297.5 & 29.75 & 100.9119 & 223.0152456 \\
April & 80.1 & 8.01 & 16.94105 & 37.43971168 \\
May & 907.8 & 90.78 & 460.1153 & 1016.854737 \\
June & 1252.1 & 125.21 & 712.5069 & 1574.640201 \\
July & 1156.8 & 115.68 & 639.7809 & 1413.915757 \\
August & 638.7 & 63.87 & 285.2357 & 630.3707885 \\
September & 254.1 & 25.41 & 81.43411 & 179.969379 \\
October & 136 & 13.6 & 34.8027 & 76.91396301 \\
November & 25.6 & 2.56 & 3.590925 & 7.935944584 \\
December & 79.4 & 7.94 & 16.74002 & 36.9954366 \\
& The annual rainfall erosivity index & & & 5312.687264 \\
Source of rainfall data: Meteorology Climatology and Geophysics Council & & & \\
\hline
\end{tabular}


Gleisol is a type of soil that has an effective depth ranging from shallow to very deep $(>120$ $\mathrm{cm})$. The gleisol color is very dark brown gray and ashy texture silty loam and sandy clay loam, rounded cube and cube structure, very closely (wet) with a $\mathrm{pH}$ of 4.8 to 6.7. This soil type is grown from the alluvium material or precipitated and dispersed in the form of brackish coastal alluvial plain land, freshwater and coastal alluvial plain floodplain (Siahaya, 1998).

Kambisol is a type of soil that has shallow to deep soil solum $(40-130 \mathrm{~cm})$. Soil color is very dark gray and fawn with sandy loam to dush loam texture, loose, finely granular to blocky, permeability moderate to slow to a $\mathrm{pH}$ of 4.8 to 6.0. This type has a parent material of sandstone, granite and periodit-serpentine. Spread on land form the structural origin of loose materials and denudasional growing from andesite parent material and landform fluvial origin-based parent alluvium (Sahuleka, 1993 and Siahaya, 1998).

Podzolic soil has an effective soil depth is very deep $(150 \mathrm{~cm})$. Soil color is dark reddish brown to dark brown with yellowish sandy loam texture, rounded cube structure, slow permeability, firm consistency (moist) with a $\mathrm{pH}$ of 4.5 to 5.0. This soil type is grown from the parent material loose rocks and andesite. Scattered on the structural origin of landforms and denudasional (Sahuleka, 1993 and Siahaya, 1998).

Here is a map of soil types at Wae Heru and Wae Tonahitu Watershed which can be seen in Figure 2 and 3.

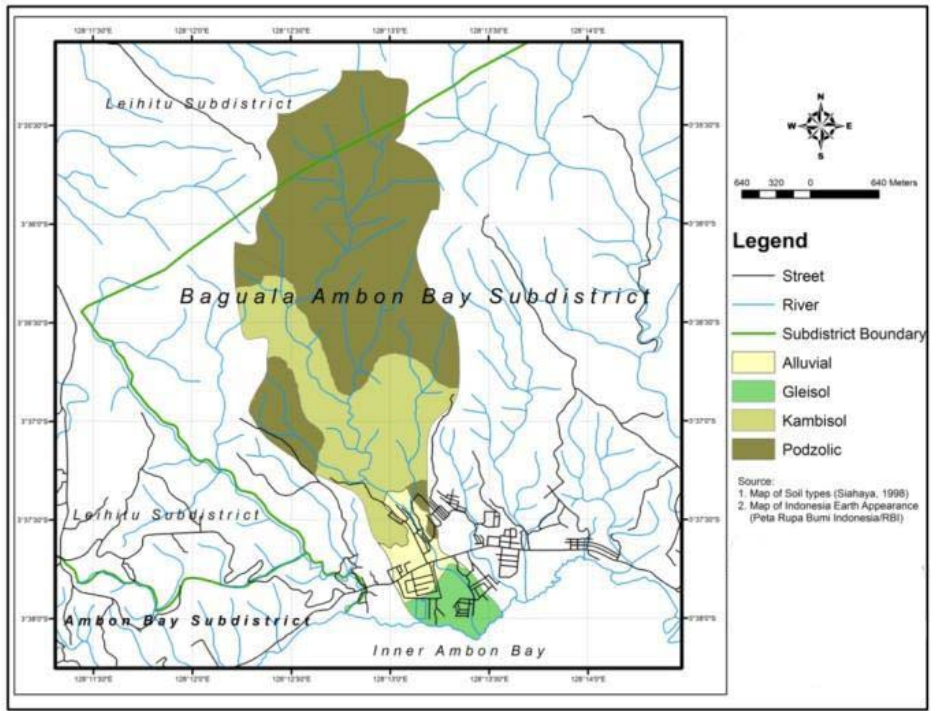

Figure 2. Map of Soil Types at Wae Heru Watershed

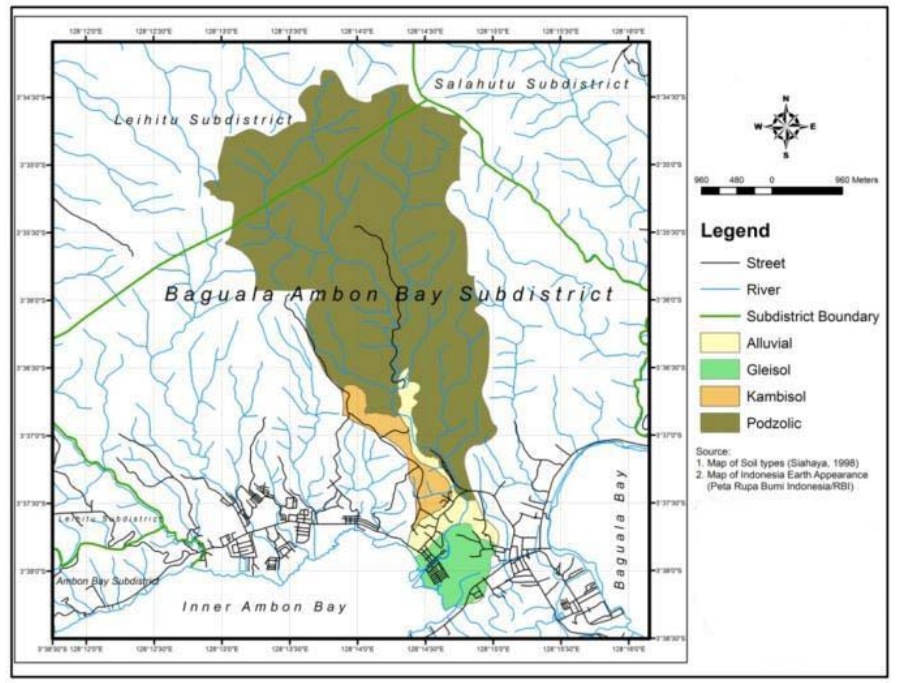

Figure 3. Map of Soil Types at Wae Tonahitu Watershed 


\section{b. Determination of the value of LS}

Ambon City area has a slope that varies, ranging from flat to steep. Flat slope generally be around at the beach

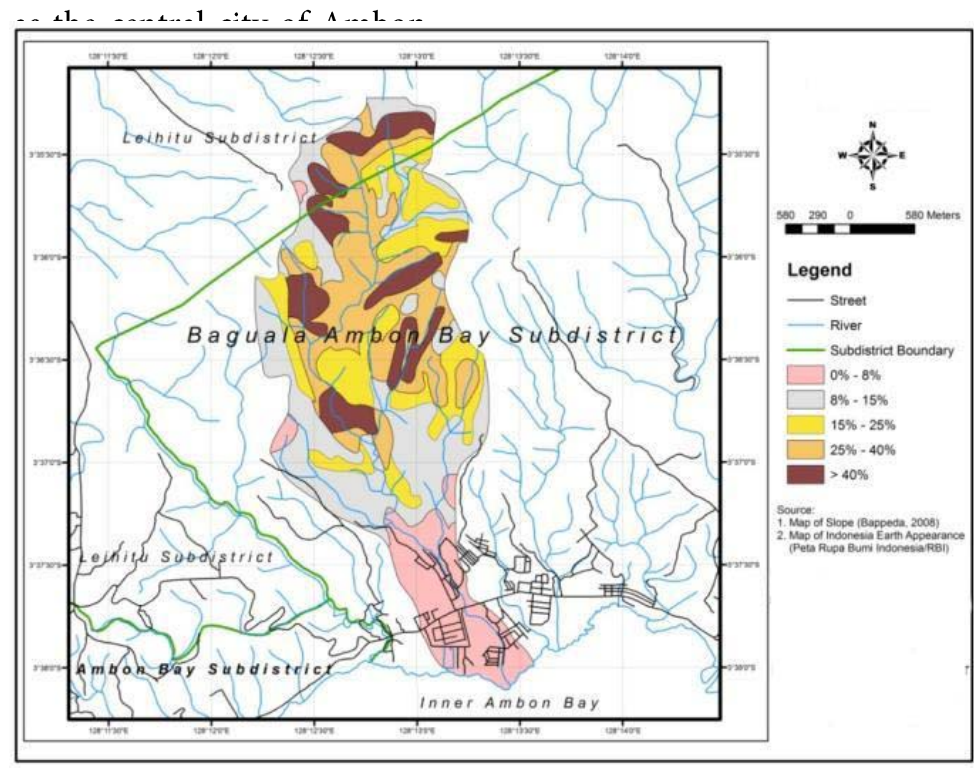

Figure 4. Map of Slope at Wae Heru Watershed

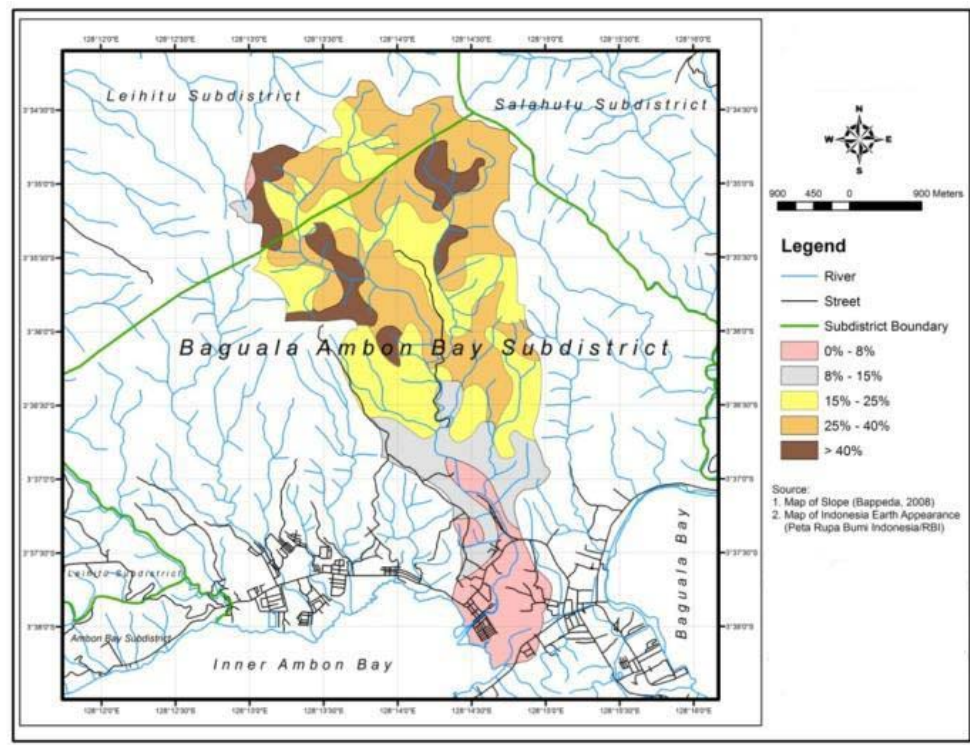

Figure 5. Map of Slope at Wae Tonahitu Watershed

Table 7. Slope at Ambon City

\begin{tabular}{llrr}
\hline Class of Slope & Category & Large (hectares) & Large (\%) \\
\hline $0-8 \%$ & Flat & 4897.36 & 13.62 \\
$8-15 \%$ & Gentle & 3580.00 & 9.96 \\
$15-40 \%$ & Tilt & 8899.97 & 24.76 \\
$>40 \%$ & Steep & 18567.51 & 51.66 \\
Amount & & 35944.84 & 100.00 \\
\hline
\end{tabular}

Source: National Land Agency of Ambon, 1995 in Asikin, 1999.
Slope in Ambon city can be seen in Table 7 as well as a map of slope at Wae Heru and Wae Tonahitu Watershed can be seen in Figure 4 and 5. 
Conditions varied from flat slopes to steep, resulting in altitude from sea level also varies. Asikin (1999) states that most areas in the city of Ambon is located at an altitude of 100-500 meters above sea level, with an area of 21202.08 hectares or $59 \%$ and approximately 9557.73 hectares or $26.59 \%$ at an altitude of 25-100 meters. Lowland area with a height of 0-25 meters, the extent of only $13.62 \%$, which are all located on the waterfront. This phenomenon also shows that the area with tilt slope to the area with steep slope directly related to the sea.

\section{c. Determination of the value of $\mathrm{C}$}

Value of C Referring to Table 3. Meanwhile, based on extracts of GeoEye imagery in 2012 and field observations then acquired some forms of land use on Wae Heru and Wae Tonahitu Watershed, the details are as follows:
1. Land use in the Wae Heru Watershed: forest (large is 533.76 hectares), homogeneous garden (large is 1.30 hectares), mixed garden (large is 24.72 hectares), mangroves (large is 7.40 hectares), settlement (large is 37.85 hectares), sand mining (large is 2.67 hectares), shrubs (large is 0.99 hectares), open land (large is 0.57 hectares) and moor (large is 65.52 hectares).

2. Land use in the Wae Tonahitu Watershed: forest (large is 1265.69 hectares), mixed garden (large is 13.04 hectares), open land (large is 13.25 hectares), mangroves (large is 33.61 hectares), settlement (large is 54.94 hectares), shrubs (large is 0.33 hectares) and moor (large is 40.40 hectares).

Here is a map of land use at Wae Heru and Wae Tonahitu Watershed which can be seen in Figures 6 and 7.

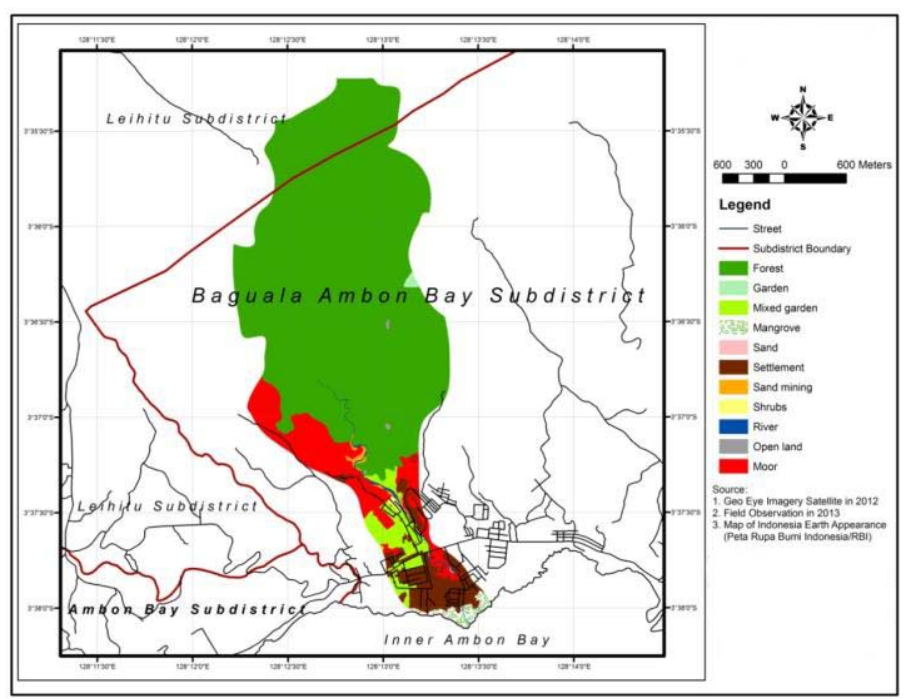

Figure 6. Map of Land Use at Wae Heru Watershed

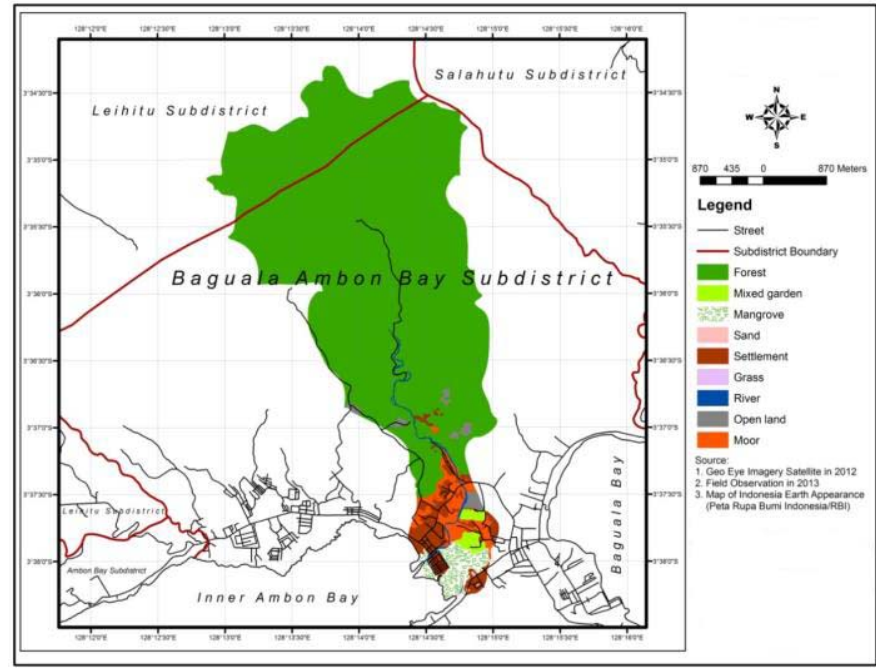

Figure 7. Map of Land Use at Wae Tonahitu Watershed 


\section{d. Determination of the value of $P$}

Value of P Referring to Table 4.

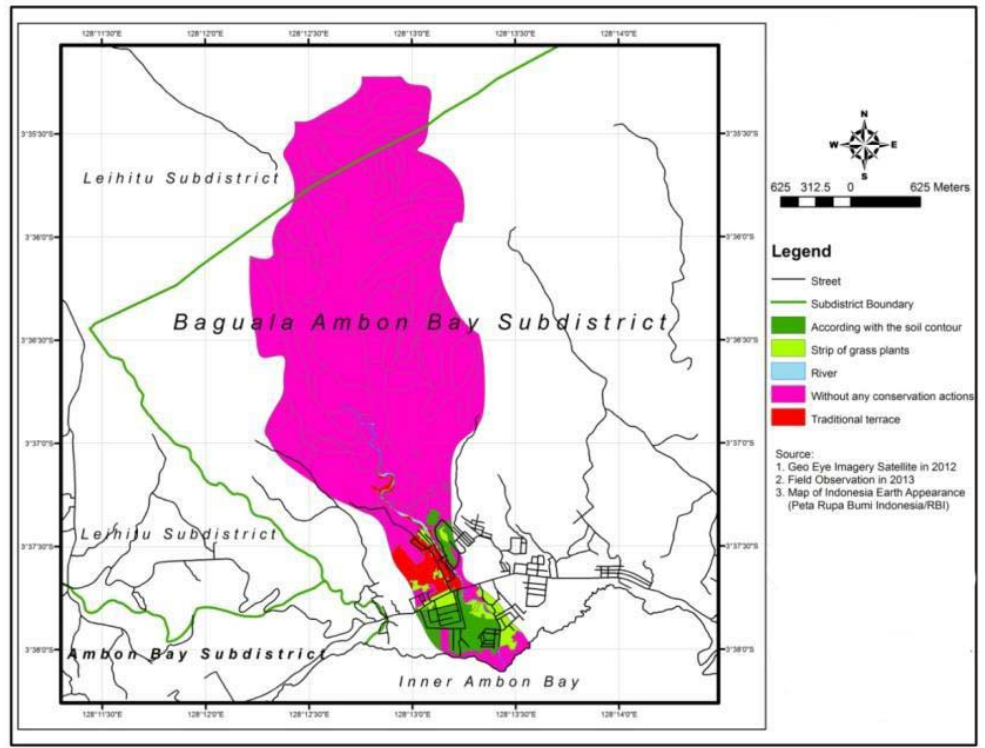

Figure 8. Map of Land Conservation at Wae Heru Watershed

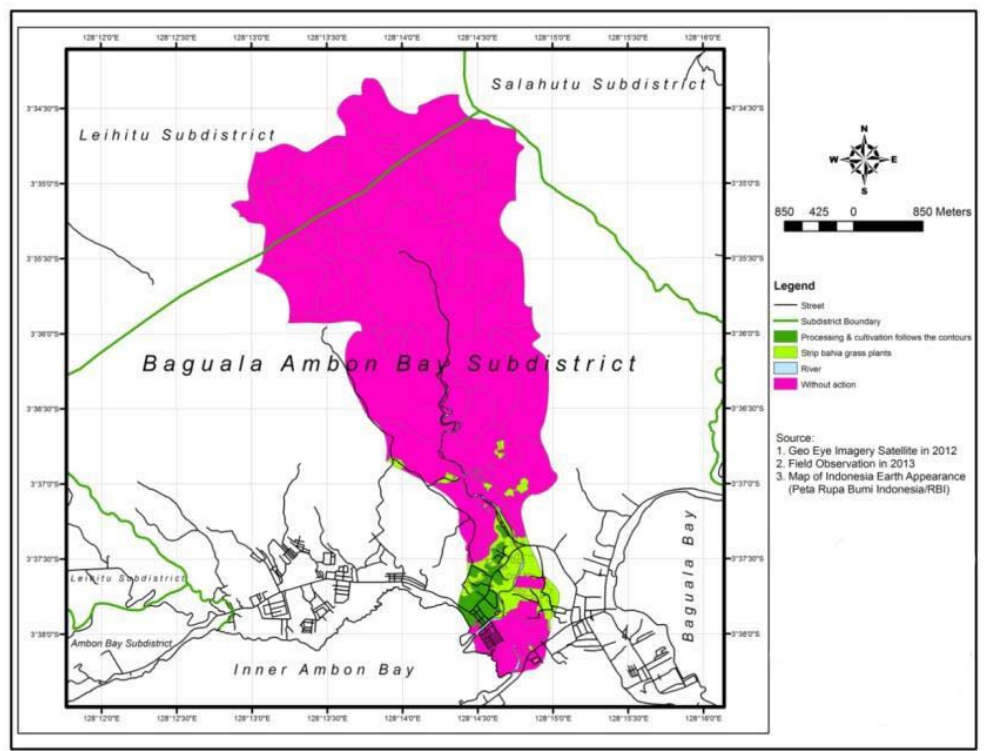

Figure 9. Map of Land Conservation at Wae Tonahitu Watershed

Based on the map (figure 8 and 9), it can be seen that no conservation acts in most areas at Wae Heru Watershed and Wae Tonahitu Watershed (on the map marked with a pink area). This is because most of the areas in the upstream still forested. In addition, there are also some areas that should be conserved, but did not do any conservation acts in the area. For example, sand mining area at Wae Heru Watershed (compare figure 6 and figure 8). In addition, areas with dense settlement also requires conservation acts.
Land management which carried out in accordance with the land contour found in some areas at the downstream (figure 8 and 9, marked with green), whereas in some locations there are land management by using a strip bahia/Paspalum notatum grass plants (figure 8 and 9 , marked with pale green). In addition, conservation acts using traditional terrace found at several locations at Wae Heru Watershed (figure 8, marked with red).

Conservation acts is important because population growth also increases the demand of fresh water supply. The combined effects will 
challenge future fresh water availability (Sun et al., 2013), i.e. streamflow, surface runoff and groundwater (Lin et al., 2007). However, surface runoff from urban areas increased and groundwater discharge decreased as replacement of vegetation through development reduces infiltration (Lin et al., 2007). Based on Li et al. (2014) the land use change may result in hydrological process variation because forest, grassland, and agricultural land are of different hydrological responses. Compared with grassland and agricultural land, forest is of higher infiltration rate and canopy interception, so there is more rainfall loss. Besides that, land use changed from grassland and agricultural land to forest, resulting in an increase in soil water storage capacity and infiltration.

\section{e. Potential of Erosion At Wae Heru and Wae Tonahitu Watershed}

According Siahaya (1998), land on two watershed area is a land with deep solum, thus determining the grade of erosion potential based on the grade level of erosion on deep soil solum, that is $>90 \mathrm{~cm}$ (Table 5). Under these conditions, erosion weighing $<15$ tons/hectare/year is very light (VL) erosion class; 15-60 tons/hectare/year is light (L) erosion class; $60-180$ tons/hectare/year is moderate (M) erosion class; 180-480 tons/hectare/year is heavy $(\mathrm{H})$ erosion class; and $>480$ tons/hectare/year is very heavy $(\mathrm{VH})$ erosion class.

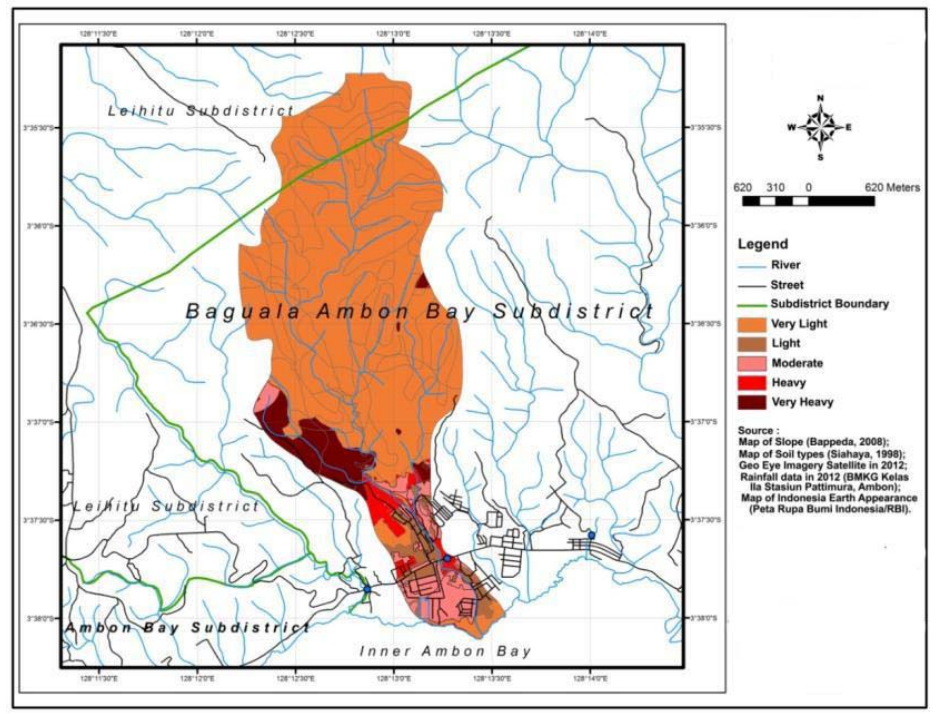

Figure 10. Map of Erosion Class at Wae Heru Watershed

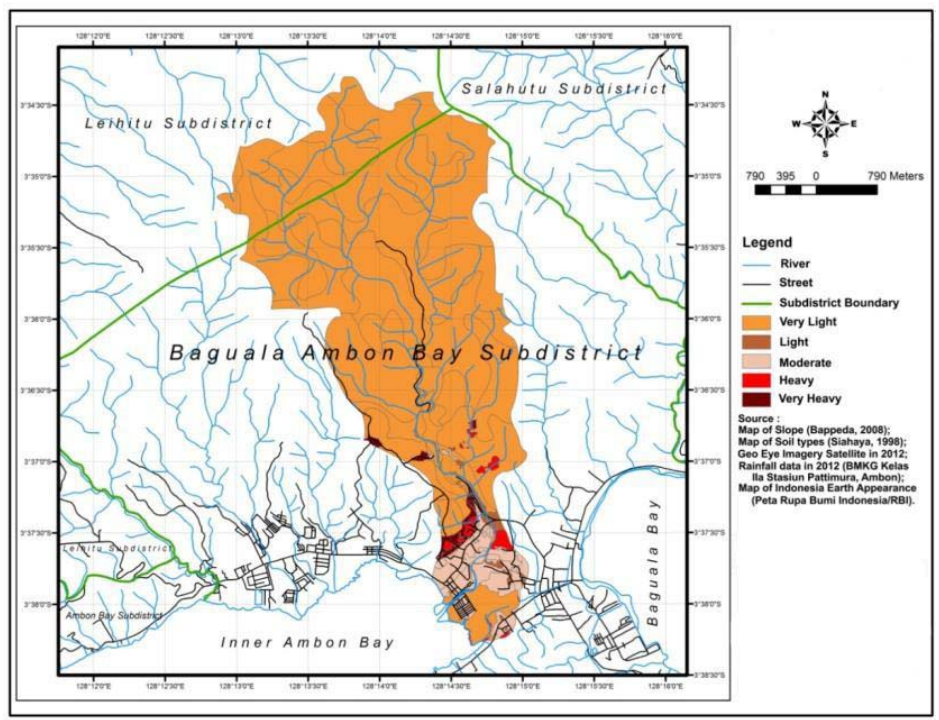

Figure 11. Map of Erosion Class at Wae Tonahitu Watershed 
Two main causes of the erosion is due to natural factors and due to human activities. Natural erosion can occur because the process of soil formation and the process to maintain the natural balance of the soil. Erosion due to natural factors still provide adequate media for the ongoing growth of most plants, while erosion due to human activity is largely due to the upper soil layer peeling due to different ways of farming that do not heed the rules of soil conservation or development activities that are destructive in physical (Asdak, 2002). It can be seen in the condition of the watershed area on Wae Heru and Wae Tonahitu, where on the map of land use and land conservation can be seen that many conservation rules are not implemented in the area.

Here is a table of land unit of slope - land use erosion class in each watershed, accompanied by the wide of each area which has been divided in percentage:

Table 8. Land unit of slope - land use - erosion class in Wae Heru Watershed

\begin{tabular}{|c|c|c|c|}
\hline Class of slope & Land use & Class of erosion & $\begin{array}{l}\text { Wide percentage (\%) from the total of } \\
\text { watershed area }\end{array}$ \\
\hline $0-8 \%$ & Forest & Very light & 1.11 \\
\hline $0-8 \%$ & Mixed garden & Light & 3.3 \\
\hline $0-8 \%$ & Mixed garden & Very light & 1.18 \\
\hline $0-8 \%$ & Mixed garden & Moderate & 0.65 \\
\hline $0-8 \%$ & Mangrove & Very light & 1.56 \\
\hline $0-8 \%$ & Sand & Heavy & 0.15 \\
\hline $0-8 \%$ & Settlement & Heavy & 0.5 \\
\hline $0-8 \%$ & Settlement & Light & 1.72 \\
\hline $0-8 \%$ & Settlement & Moderate & 5.5 \\
\hline $0-8 \%$ & Sand mining & Heavy & 0.2 \\
\hline $0-8 \%$ & Sand mining & Moderate & 0.07 \\
\hline $0-8 \%$ & Shrubs & Moderate & 0.2 \\
\hline $0-8 \%$ & River & Very light & 0.5 \\
\hline $0-8 \%$ & Open land & Heavy & 0.02 \\
\hline $0-8 \%$ & Moor & Heavy & 3.21 \\
\hline $0-8 \%$ & Moor & Light & 0.04 \\
\hline $0-8 \%$ & Moor & Moderate & 2.12 \\
\hline $8-15 \%$ & Forest & Very light & 34.05 \\
\hline $8-15 \%$ & Mixed garden & Heavy & 0.04 \\
\hline $8-15 \%$ & Garden & Heavy & 0.02 \\
\hline $8-15 \%$ & Settlement & Very heavy & 0.2 \\
\hline $8-15 \%$ & Sand mining & Very heavy & 0.25 \\
\hline $8-15 \%$ & River & Very light & 0.1 \\
\hline $8-15 \%$ & Open land & Very heavy & 0.04 \\
\hline $8-15 \%$ & Moor & Very heavy & 7.8 \\
\hline $15-25 \%$ & Forest & Very light & 9.5 \\
\hline $15-25 \%$ & Sand mining & Very heavy & 0.02 \\
\hline $15-25 \%$ & River & Very light & 0.03 \\
\hline $15-25 \%$ & Moor & Very heavy & 0.49 \\
\hline $25-40 \%$ & Forest & Very light & 7.07 \\
\hline $25-40 \%$ & Garden & Very heavy & 0.23 \\
\hline $25-40 \%$ & River & Very light & 0.02 \\
\hline $25-40 \%$ & Open land & Very heavy & 0.05 \\
\hline$>40 \%$ & Forest & Very light & 18.03 \\
\hline$>40 \%$ & Garden & Very heavy & 0.02 \\
\hline$>40 \%$ & River & Very light & 0.01 \\
\hline
\end{tabular}


The greatest percentage is in the condition of the 8$15 \%$ slope class with the land use is forest with class of erosion is very light (number 18); followed by land on a slope $>40 \%$ with the land use is forest and class of erosion is very light (number 34); and the third position is still the same of land use and erosion class, but the slope is $15-25 \%$ (number 26 ). The trio dominated the existing land use in Wae Heru watershed, that is in the form of forest. But in the next extents, land use is moor with class of erosion is very heavy in the slope of $8-15 \%$ (number 25 ) found in this watershed, with a wide percentage is $7.8 \%$ from the total of watershed area.

When viewed as a whole, the area with very heavy erosion class covers $9.1 \%$ of the total area of the watershed, followed by $4.14 \%$ and $8.54 \%$ for areas with heavy erosion and moderate erosion respectively. While the area with light erosion class amounted to $5.06 \%$ of total area. Thus large area with very light erosion class amounted to $73.16 \%$. Despite wide area with very light erosion class still dominates, but it should be seen that the form of land use in areas with erosion class is moderate to very heavy is garden, open land, moor, sand mining and settlement found in some areas in the central part of the watershed and the whole area of downstream. The forms of land use that is likely to increase in the years ahead due to population growth, the necessities of life, exploration and other development forms. It should be noted that the extent of the area is not increasing, even should be limited. Furthermore, by looking at the table, it can be seen that forest is a form of land use that maintains and protects most of the watershed areas so the erosion class is very light dominate this watershed areas, then for the conversion of forest lands should be limited with very tight, accompanied by conservation acts with high intensity.

For example, in this watershed area there are sand mining activities are located in the slope of $0-8 \%, 8-15 \%$ and $15-25 \%$, with the potential erosion is moderate to very heavy. Then, by looking at a map (Figure 10), sand mining site located in the middle area of the watershed. This is a simple indication of exploitation in watershed areas that propagate toward the upstream area. For that, the ex-mining lands have to do intense conservation efforts so that the potential erosion can be decreased to be light or very light. Moreover, the statistics show that the population growth in Ambon city is increasing every year, then according to Noori et al (2016), it may be a cause of land clearing and can occur continuously.

Table 9. Land unit of slope - land use - erosion class in Wae Tonahitu Watershed

\begin{tabular}{|c|c|c|c|}
\hline Class of slope & Land use & Class of erosion & $\begin{array}{l}\text { Wide percentage (\%) from the total } \\
\text { of watershed area }\end{array}$ \\
\hline $0-8 \%$ & Forest & Very light & $\begin{array}{ll}+3 \\
\end{array}$ \\
\hline $0-8 \%$ & Mixed garden & Moderate & 2.85 \\
\hline $0-8 \%$ & Mangrove & Very light & 7.34 \\
\hline $0-8 \%$ & Sand & Heavy & 0.2 \\
\hline $0-8 \%$ & Settlement & Heavy & 0.12 \\
\hline $0-8 \%$ & Settlement & Light & 1.06 \\
\hline $0-8 \%$ & Settlement & Moderate & 9.41 \\
\hline $0-8 \%$ & Grass & Light & 0.07 \\
\hline $0-8 \%$ & River & Very light & 1.06 \\
\hline $0-8 \%$ & Open land & Heavy & 1.07 \\
\hline $0-8 \%$ & Open land & Moderate & 0.1 \\
\hline $0-8 \%$ & Moor & Light & 1.36 \\
\hline $0-8 \%$ & Moor & Moderate & 5.8 \\
\hline $8-15 \%$ & Forest & Very light & 32.56 \\
\hline $8-15 \%$ & Settlement & Heavy & 1.17 \\
\hline $8-15 \%$ & Settlement & Very heavy & 0.24 \\
\hline $8-15 \%$ & Settlement & Moderate & 0.1 \\
\hline $8-15 \%$ & River & Very light & 0.3 \\
\hline $8-15 \%$ & Open land & Heavy & 0.85 \\
\hline
\end{tabular}




\begin{tabular}{lllr}
\hline $8-15 \%$ & Open land & Very heavy & 0.76 \\
$8-15 \%$ & Moor & Heavy & 0.02 \\
$8-15 \%$ & Moor & Very heavy & 1.7 \\
$15-25 \%$ & Forest & Very light & 10.48 \\
$15-25 \%$ & River & Very light & 0.11 \\
$15-25 \%$ & Open land & Very heavy & 0.12 \\
$25-40 \%$ & Forest & Very light & 10.85 \\
$>40 \%$ & Forest & Very light & 3 \\
\hline
\end{tabular}

Wae Tonahitu Watershed conditions it does not differ much from Wae Heru Watershed conditions. At various slope, most of the land in condition of very light erosion class (73\%), with the majority of land use is forest. And approximately $2.82 \%$ of the total area is in condition of very heavy erosion class; $3.43 \%$ in conditions of heavy erosion class; $18.26 \%$ in condition of moderate erosion class and $2.49 \%$ in condition of light erosion class, with dominated forms of land use is moor, settlement, open land and mixed garden. This condition is most commonly found in the downstream area of watershed. So as mentioned earlier, that the forms of land use that must be observed, so the extent of that area does not continue to grow in the coming years, otherwise the land use of forest should be maintained in order to preserve the watershed.

The trend of the downstream areas of watershed has the most potential class of moderate to very heavy, because the downstream area has a slope is not steep $(0-8 \%$ and $8-15 \%)$, so that the activity of land conversion and land clearing is going a lot in here. As a solution, then Sun et al. (2013) states that to develop the watershed sustainably, it is necessary to examine these future growth areas carefully in terms of their resources (such as safe drinking water supply), environmental constraints (e.g., mountainous terrain), infrastructures and superstructures (such as transportation networks), and socio-economic conditions (including job opportunities), so that sound planning strategies can be formulated.

\section{Conclusion}

1. Potential erosion of Wae Heru Watershed and Wae Tonahitu Watershed are in very light potential class, wherein the condition is found mostly in the upstream area with land use is forest. Meanwhile, downstream area dominated by various forms of land use such as settlement, garden, moor, open land and sand mining, so that the land was in light to very heavy condition of erosion.

2. Condition of upstream areas, mostly in the form of forest must be maintained, by limiting the attempted exploitation of land and intense conservation efforts to land that had already been exploited. This is also a form of anticipation to the growth of human population which is increasing rapidly, which may endanger the sustainability of the watershed areas, particularly in the upstream.

\section{Acknowledgements}

Thank you to The Institute of Education Fund Management, The Finance Ministry of The Republic of Indonesia that has funded this research through a Thesis and Dissertation Scholarship Program Phase II in 2013.

\section{References}

Arsyad, S (2006), Conservation of Soil and Water, Bogor Agricultural University Press, Bogor (in Indonesian).

Asdak, C (2002), Hydrology and Watershed Management, Gadjah Mada University Press, Yogyakarta (in Indonesian).

Asikin, E (1999), Inner Ambon Bay Water Quality Conformance For Fish Farming, Thesis, Study Program in Environmental Sciences, Graduate Program, Gadjah Mada University, Yogyakarta (in Indonesian).

Berhitu, P.Th., and Y. Matakupan (2007), Feasibility Study on Coastal Area Development in Ambon City As the City of Beach (Ambon Water Front City), Jurnal Teknologi, Volume 7, Number 1 (in Indonesian).

Departement of Forestry (1994), The decision of General Director of Reforestation and Land Rehabilitation, Number 073/Kpts/V/1994 
about Guidelines for Preparation of Technical Plan for Land Rehabilitation and Watershed Soil Conservation, Departement of Forestry, Jakarta (in Indonesian).

Development Planning Agency at Ambon City (2008), Map of Slope at Ambon City, Development Planning Agency, Ambon (in Indonesian).

Directorate General of Reforestation and Land Rehabilitation (1998), Guidelines for Preparation of Technical Plan for Land Rehabilitation and Watershed Soil Conservation, Departement of Forestry, Jakarta (in Indonesian).

Kurnia, Rachman, and Dariah (2004), Soil Conservation Technology On sloping land, Centre for Research and Development of Soil and Agroclimate, Agency for Agricultural Research and development, Departement of Agriculture (in Indonesian).

Latupono, S (2005), Environmental Damage Assessment Due Sand Mining And Stone Mining In Waeheru Village, Districts of Ambon Baguala Bay, Ambon City, Thesis, Environmental Management Master Program, Inter-Sector Programs, Graduate School, Gadjah Mada University, Yogyakarta (in Indonesian).

Li, J., P. Feng., and F. Chen (2014), Effects of land use change on flood characteristics in mountainous area of Daqinghe watershed, China, Nat Hazards, 70, 593-607, DOI 10.1007/s11069-013-0830-8.

Lin, Y.P., N.M. Hong., P.J. Wu., and C.J. Lin (2007), Modeling and assessing land-use and hydrological processes to future land-use and climate change scenarios in watershed landuse planning, Environ Geol, 53, 623-634, DOI 10.1007/s00254-007-0677-y.

Loppies, C.Z (1992), Assessment of Land Use Pattern of Coastal Ecosystems in Ambon Bay Through Air Photo, Thesis, Graduate School, Gadjah Mada University, Yogyakarta (in Indonesian).

Meteorology Climatology and Geophysics Council (2012), Report of Rainfall Data and Total Amount of Rainfall Days, Meteorology Climatology and Geophysics Council, Class of 1a, Pattimura Stations, Ambon (in Indonesian).
Noori, N., L. Kalin., S. Sen., P. Srivastava., and C. Lebleu (2016), Identifying areas sensitive to land use/land cover change for downstream flooding in a coastal Alabama watershed, Reg Environ Change, DOI 10.1007/s10113016-0931-5.

Sahuleka, W (1993), Surface Erosion Study On Jazirah Leitimur of Ambon Island, Thesis, study Program of Geography, Department of Mathematics and Natural Sciences, Gadjah Mada University, Yogyakarta (in Indonesian).

Samalehu, H (2013), Analysis of Soil Erosion and Conservation Techniques of Wae Ruhu Watershed in Ambon, Thesis, Master of Water Resources Management, Department of Civil and Environmental Engineering, Graduate Program, Gadjah Mada University, Yogyakarta (in Indonesian).

Siahaya, W.A (1998), Aerial Applications and Geographic Information System to Assess Soil And Spatial Ability of Municipal Agriculture at Jazirah Leihitu Ambon, Thesis, Study Program of Remote Sensing, Department of Mathematics and Natural Sciences, Graduate Program, Gadjah Mada University, Yogyakarta (in Indonesian).

Sun, Y., S.T.Y. Tong., M. Fang., and Y.J. Yang (2013), Exploring the effects of population growth on future land use change in the Las Vegas Wash watershed: an integrated approach of geospatial modeling and analytics, Environ Dev Sustain, 15, 14951515, DOI 10.1007/s10668-013-9447-z.

The Central Bureau of Statistics in Ambon (2012), Ambon City In Numbers, UD Aman Jaya (in Indonesian).

The Central Bureau of Statistics in Ambon (2015), Ambon City In Numbers, UD Aman Jaya (in Indonesian).

The Central Bureau of Statistics in Ambon (2012), Subdistrict of Baguala Ambon Bay In Numbers, UD Aman Jaya (in Indonesian).

Tokarczyk, T (2013), Classification of Low Flow and Hydrological Drought for a River Basin, Acta Geophysica, 61, 2, 404-421, DOI: 10.2478/s11600-012-0082-0.

Walia, D., and B.S. Mipun (2010), Hydrological Behavior of Umshing River-East Khasi Hills-Meghalaya, Acta Geophysica, 58, 5, 908-921, DOI: 10.2478/s11600-010-0018-5. 
Wischmeier, W.H., and D.D. Smith (1978), Predicting rainfall erosion losses: guide to conservation planning. USDA, Agriculture
Handbook 537, U.S. Government Printing Office, Washington DC. 